\title{
Foreword
}

\section{Independence and Interdependence: Mutual Reinforcement}

\section{Ernesto Zedillo}

One of the most popular adventure novels in the history of world literature, Robinson Crusoe, was first published in 1719, but its message of independence, self-reliance and self-sufficiency still fascinates minds and spirits. However, the fictional story of an English castaway who spent 28 years on a remote island before being rescued by compatriots stirs the reader's imagination largely due to the improbability. Indeed, the real-life castaway, Scottish sailor Alexander Selkirk, who is often considered to be Crusoe's prototype, was rescued after only four years on an uninhabited island. Writer James Joyce interpreted Crusoe as the true example of the British colonist whose mission is expansion rather than seclusion. As if acknowledging the growing interdependence of the eighteenth-century world ruled by the exploration and colonization impulse, Daniel Defoe's novel ends with its protagonist's return to the same island, which has since been discovered.

In the twenty-first century, distances have become largely irrelevant, the remaining uninhabited islands have been discovered, if not populated, and 'Robinsons' on remote islands hardly lack connection with the rest of the world in the era of an information technology revolution. Moreover, man-made barriers to the exchange of goods and ideas and to travel have been lowered or removed. Global interconnectedness is now manifested in terms of trade, capital flows and migration. With the colonial past left behind us, modern national sovereignties celebrate their independence. However, in light of the promise of a better life through globalization, they can gain more from their independence if they capitalize on interdependence. In reference to developing countries, I have said elsewhere that 'We are now independent to the extent that we are interdependent'.

Sure, there still remain 'castaway' nations existing at the margins of the 
global economy and polity. Millions of people are living in abject conditions on the fringes of the interdependent world. The dilemma of whether to embrace or reject globalization continues to face many countries. And the way in which this dilemma is addressed by nation states and civil societies will have a decisive influence on the character of modern times. Depending on the resolution of this dilemma, the twenty-first century will be remembered in history as an arena of great success or great failure.

My deep persuasion is that interdependence among countries can be beneficial for all parties and that global integration is part of the solution to the problems of poverty and inequality. The biggest present-day challenge is inclusion of the have-nots in the process of globalization. Time and again it has been shown that when people lack education; adequate training; good health; basic human, political and property rights; security; and elementary infrastructure, they cannot take advantage of the tremendous opportunities presented by the market economy. Two billion people, including a high proportion of the world's poor, live in countries which have scant involvement in the global economy. These countries, many in Africa, have minimal participation in world markets, exporting a few commodities and importing negligible quantities of goods, and many had negative economic growth throughout most of the 1980s and 1990s. Within other developing countries, extreme poverty is found precisely in those regions and communities which contemporary globalization has left largely untouched. For example, the problem for subsistence peasants in any developing country is not that globalization has reached them, but rather the opposite: they remain outside the world market.

The formally independent but marginalized nations risk losing their sovereignty because of their economic weakness and political instability. Every country - poor as well as rich - needs other countries' markets, capital and in some cases population flows in order to support its own economic expansion. Therefore, interdependence is indispensable for the pursuit of prosperity, peace and security. It is also critical for preservation and strengthening of true independence.

I do not tire of emphasizing that global integration is not a given. It is not irreversible, as some claim, based on the wrong belief that the phenomenon is essentially driven by technological change in transportation and telecommunications. Contemporary interdependence urged by political decisions can also be overturned, with a resultant dislocating, and even destructive, effect on global integration. Promoting a globalization which would offer opportunities to all involved requires effective political decision making at both national and international levels.

The developed countries can no longer insulate themselves in a cocoon of prosperity, while many developing countries linger in misery. Rich nations are 
responsible for world development, and this is reflected in their engagement in the international arena to facilitate trade, provide aid for development and address the issues of migration. This pro-development agenda should empower the disadvantaged to participate, with a credible chance of success, in the global market economy. However, the primary responsibility for achieving growth and equitable development lies with the developing countries themselves. It is at the national level that sovereign states make decisions to foster the market economy by opening it to foreign trade and liberalizing financial markets. It is through solid national policies that the countries' independence can be further advanced and their positions in the interdependent world improved.

True, global integration, like any economic and social process, has downsides. Although economic and political openness is expected to generate global gains that far exceed the losses, the benefits of globalization are not distributed equally across countries and populations. But it is also true that effective policies and strong institutions at the local, national and international levels can significantly limit the negative aspects of interdependence and strengthen its potential to be a force for good. Apart from an altruistic sentiment, addressing the challenges of globalization is in the self-interest of all countries - both poor and rich, weak and powerful.

The project Global Trade and Financial Architecture, that I had recently the honor of leading, has been driven by the aspiration for equity in governing globalization. In our report of the project results, we acknowledge that there will be losers from multilateral liberalization of access to markets - and suggest the means to compensate for the losses and assist the disadvantaged groups. ${ }^{2}$ We also recognize that the poorest developing countries cannot benefit from economic openness unless they build physical, human and institutional capacity to trade. Therefore, a significant increase in well-targeted 'aid for trade' is proposed. Finally, we recommend moving away from providing exceptions from international rules to developing countries in favor of helping them meet development goals and advocate establishing a global program on policy transparency.

The project ideas and proposals are consistent with the letter and spirit of this book. The contributors to this volume - all of whom are associated with the Global Development Network, which fosters high-quality socio-economic research in and about the developing world - are also concerned about costs and benefits of global interdependence. They specifically address the question of countries' adjustment to the perils of globalization, that I consider to be central for attracting developing countries into the global economy. Indeed, any scheme of compensation to the losers from trade liberalization should take into account the adjustment costs and the fact that these costs are incurred before one can take advantage of new trade opportunities. In devising such 
schemes, assigning different roles to bilateral and multilateral development assistance - contemplated by some contributors to this volume - can prove helpful.

It is no wonder that this publication addresses a diversity of issues on trade, aid and migration: these issues are interconnected in their relation to development. 'Aid for trade,' to which I attribute much importance, testifies to this interconnectedness. Migration also enters the development field, particularly as a result of internationalization of the services sector. This collection of articles also brings to mind that the rationale for global integration is not only economic. Contacts generated by trade, investment and migration may serve to sensitize a country's population to the values, cultures and customs of other countries. Whenever people believe that economic interdependence serves their own self-interest - by giving them better opportunities to improve their well-being - these contacts encourage a convergence of values that reduce the risk of violent conflict among interdependent nations. For these and many other reasons, constructive interdependence must not be allowed to falter.

We are reminded by many accounts - academic, literary and journalistic that it takes much courage, will, intelligence and endurance to be independent. But no less courage, will, intelligence and endurance are needed to embrace interdependence and extract dividends from it. While it is rather difficult nowadays to be left alone, many nations and groups are still left behind. To lift them from their 'castaway' status, international cooperation is imperative. The experiences of countries, such as those analyzed in this book, can serve as useful reference points in policymakers' efforts to make the global economy more inclusive and receptive to the newcomers.

\section{NOTES}

1. Ernesto Zedillo (2001), 'Globalization and the Changing Roles of States'. Remarks at the 2001 annual meeting of the Trilateral Commission, London, 10 March 2001, available at http: //www.trilateral.org/annmtgs/trialog/trlgtxts/t55/zed.htm.

2. 'Strengthening the Global Trade Architecture for Economic Development: An Agenda for Action'. Policy brief of the project on 'Global Trade and Financial Architecture', spearheaded by the Department for International Development and the Yale Center for the Study of Globalization, New Haven, Connecticut, 2005, available at http://www.ycsg.yale.edu/focus/ index.html 